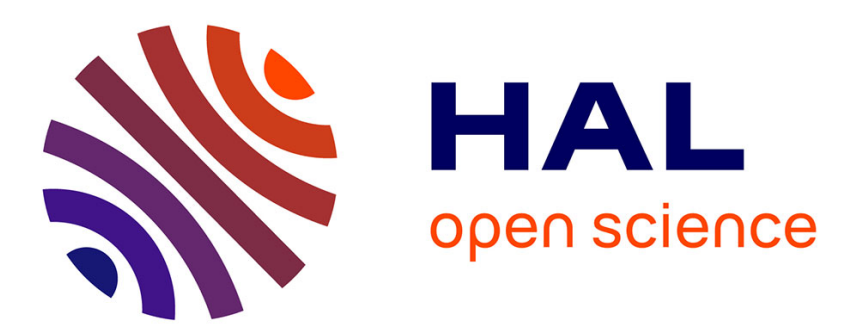

\title{
Impact of sheep grazing on juvenile sea bass, Dicentrarchus labrax L., in tidal salt marshes
}

Pascal Laffaille, Jean-Claude Lefeuvre, Eric Feunteun

\section{To cite this version:}

Pascal Laffaille, Jean-Claude Lefeuvre, Eric Feunteun. Impact of sheep grazing on juvenile sea bass, Dicentrarchus labrax L., in tidal salt marshes. Biological Conservation, 2000, vol. 96, pp.271-277. 10.1016/S0006-3207(00)00081-1 . hal-00762030

\section{HAL Id: hal-00762030 https://hal.science/hal-00762030}

Submitted on 6 Dec 2012

HAL is a multi-disciplinary open access archive for the deposit and dissemination of scientific research documents, whether they are published or not. The documents may come from teaching and research institutions in France or abroad, or from public or private research centers.
L'archive ouverte pluridisciplinaire HAL, est destinée au dépôt et à la diffusion de documents scientifiques de niveau recherche, publiés ou non, émanant des établissements d'enseignement et de recherche français ou étrangers, des laboratoires publics ou privés. 


\title{
Impact of sheep grazing on juvenile sea bass, Dicentrarchus labrax L., in tidal salt marshes
}

\author{
P. Laffaille*, J.-C. Lefeuvre, E. Feunteun \\ UMR 6553 Ecobio, Université de Rennes 1, avenue du Général Leclerc, 35042 Rennes cedex, France
}

\begin{abstract}
The diet of young of the year sea bass, Dicentrarchus labrax L., from sheep grazed and ungrazed tidal salt marshes were compared qualitatively and quantitatively in Mont Saint-Michel Bay. In areas without grazing pressure, the vegetation gradient changes from a pioneer Puccinellia maritima dominated community at the tidal flat boundaries through a Atriplex portulacoides dominated community in the middle of the marsh to a mature Elymus pungens dominated community at the landward edge. The A. portulacoides community is highly productive and provides important quantities of litter which provides a habitat and good supply to substain high densities of the detrivorous amphipod Orchestia gammarellus. In the grazed areas, the vegetation is replaced by $P$. maritima communities, a low productive grass plant, and food availability and habitat suitability are reduced for $O$. gammarellus. Juvenile sea bass colonise the salt marsh at flood during $43 \%$ of the spring tides which inundate the salt marsh creeks. They forage inside the marsh and feed mainly on $O$. gammarellus in the ungrazed marshes. In grazed areas, this amphipod is replaced by other species and juvenile sea bass consume less food from the marsh. This illustrates a direct effect of a terrestrial herbivore on a coastal food web, and suggests that management of salt marsh is complex and promotion of one component of their biota could involve reductions in other species.
\end{abstract}

Keywords: Dicentrarchus labrax; Feeding; Tidal salt marsh; Sheep; Grazing; Interaction; Engineer species

\section{Introduction}

Salt marsh generally has a very high conservation value, directly as a result of their species complement and their role as a feeding ground for migrant birds (Schricke, 1983; Lefeuvre et al., 1994, 2000; Norris et al., 1997), but also indirectly as an important feeding ground for fish, especially juveniles (Boesch and Turner, 1984; Minello and Zimmerman, 1992; Rozas and Reed, 1993; Kneib, 1997; Laffaille et al., 1998, 1999). The salt marsh ecosystem, therefore, acts as an important interface between the terrestrial and marine habitats, and as such, comes under pressure from both ends (reclamation, overfishing, overgrazing) (e.g. Bakker, 1989; Lefeuvre, 1992; Lin and Beal, 1995). In this paper we will examine one of the interactions across this interface, the impact of sheep grazing on juvenile sea bass within the Mont Saint-Michel bay on the Atlantic coast of France.

*Corresponding author. Tel.: + 33-2-9928-6824; fax: + 33-2-9928-1458.

E-mail address: pascal.lafaille@univ-rennes1.fr (P. Laffaille)
Sea bass, Dicentrarchus labrax L., is one of the most abundant commercial species of the Atlantic coast, and most research on this species has focused on its production and farming. Only a few studies have been concerned with its ecology (Pickett and Pawson, 1994; Pawson and Pickett, 1996), though knowledge of the feeding ecology of young stages is, for example, necessary to understand mortality within age classes (Arrhenius, 1996). Sea bass is one of the most abundant species in Mont SaintMichel bay (Feunteun and Laffaille, 1997), where young fish, and especially the young of the current year (referred to here as juveniles), occur frequently at high densities in mudflats and in the creeks of vegetated salt marshes (Laffaille et al., 1998, 2000).

Most European salt marsh grazed by domestic stock, usually cattle or sheep (Bakker, 1989). In Mont SaintMichel Bay three-quarters of salt marsh area (30-32 $\mathrm{km}^{2}$ ) are grazed by 17000 ewes. This grazing has caused important impacts on the habitat structure, including a transformation from a highly productive Atriplex portulacoides community to low productively Puccinellia maritima community with a lower production (Guillon, 
1984; Bouchard et al., 1995; Bouchard, 1996; Vivier, 1997). However, almost nothing is known about the impacts of this grazing pressure, whether direct or indirect via change in community structure, on other parts of the ecosystem, including fish populations. Here we make a preliminary study of the impacts of sheep grazing on juvenile sea bass by comparing fish diets in grazed and ungrazed parts of the marsh.

\section{Methods}

\subsection{Study site}

Mont Saint-Michel Bay is a wide littoral zone situated in the Normano-Breton Gulf of France (Latitude $48^{\circ} 40^{\prime}$ $\mathrm{N}$, Longitude $1^{\circ} 40^{\prime} \mathrm{W}$ ) extending over $500 \mathrm{~km}^{2}$ (Fig. 1). This bay is a macrotidal system with the second highest tidal range in Europe (mean: 10-11 m; maximum: 16 $\mathrm{m})$. The intertidal zone covers $220 \mathrm{~km}^{2}$, including 180 $\mathrm{km}^{2}$ of mud flats and $40 \mathrm{~km}^{2}$ of salt marsh. The salt marsh is incised by a more or less dense creek network where sea water comes in during the tidal cycles. Sea water reaches these creeks when the water level is $>11.25 \mathrm{~m}$; approximately in $43 \%$ of tides. The salt marsh vegetation is flooded when the water level is $>12.40 \mathrm{~m}(5-10 \%$ of the tides). This salt marsh complex of tidal creeks and vegetated tidal flats can be invaded by fish only during these spring tides, and for a very short period (1-2 h) during each tide (Troccaz et al., 1994; Laffaille et al., 1998). These characteristics are the principal differences between European and north-east American salt marshes which are inundated twice a day by tide (Morley, 1973; Beeftink, 1977; McKee and Patrick, 1988).

Our study sites were located in the vegetated salt marshes. They were distributed in salt marshes between Mont Saint-Michel and the 'Polder Bertrand' $(15 \mathrm{~km}$ distance). The distance from the minimum sea level increased from east to west. Four creeks, two in ungrazed and two in gazed zones of salt marshes were chosen because: (1) they presented similar widths (10 to $15 \mathrm{~m}$ wide) and they were near to vegetated/unvegetated salt marsh boundaries; and (2) they presented different vegetation characteristics, as a result of differential grazing pressures.

A game reserve of about $7 \mathrm{~km}^{2}$ of salt marshes was created to avoid sheep grazing and hunting. According to Bouchard et al. (1995), Bouchard (1996), Bouchard and Lefeuvre (1996) and Lefeuvre et al. (1994, 2000), the plant community is mainly structured along a submersion gradient. Three zones are distinguished: the pioneer zone is characterised by very short vegetation $(<5 \mathrm{~cm})$ dominated by Salicornia spp. and Puccinellia maritima and the production is about $2-5 \mathrm{t} \mathrm{ha}^{-1} \mathrm{y}^{-1}$ of organic matter (OM) net aerial dry production (NADP); the middle zone dominated by Atriplex portulacoides (20-25 t OM $\left.\mathrm{ha}^{-1} \mathrm{y}^{-1}\right)$ with tall stems (50-70 cm high) and the mature zone dominated by Elymus pungens (15-20 t OM

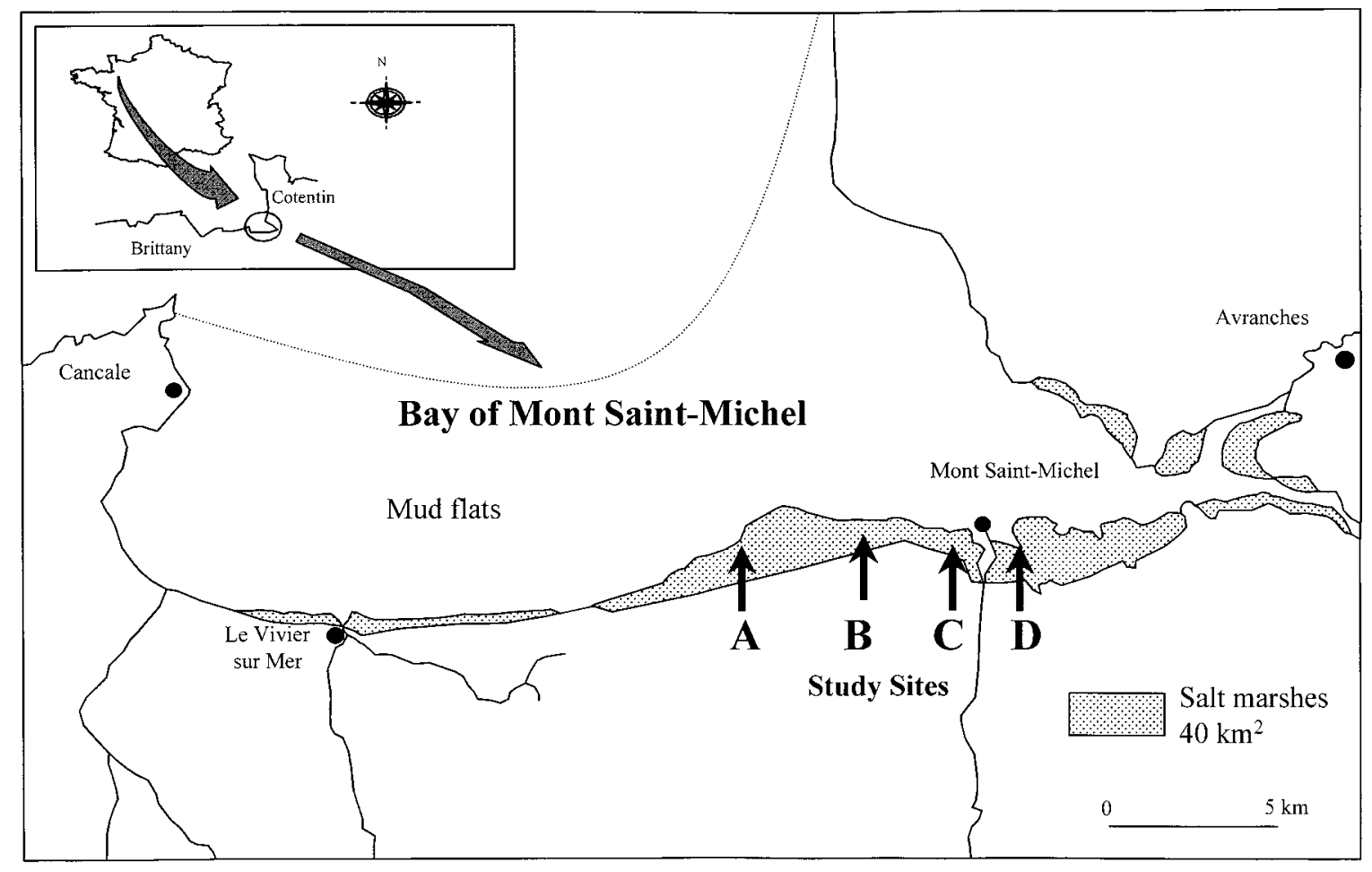

Fig. 1. Location of the Mont Saint-Michel Bay and the four study sites (A, B, C and D). 
$\left.\mathrm{ha}^{-1} \mathrm{y}^{-1}\right)$. Two sites were selected in ungrazed vegetated areas: sites B and C (see Fig. 1).

In grazed areas $\left(30-32 \mathrm{~km}^{2}\right)$, the vegetation zones disappear and are replaced by a nearly monospecific $P$. maritima community $\left(3-6 \mathrm{t} \mathrm{OM} \mathrm{ha} \mathrm{O}^{-1} \mathrm{y}^{-1}\right)$. This is a known missing consequence of grazing by herbivores in many European salt marshes (Guillon, 1984; Bakker, 1989; Kiehl et al., 1996; Vivier, 1997). Therefore, this area is much less productive than the ungrazed one dominated by $A$. portulacoides (20-25 t OM ha ${ }^{-1} \mathrm{y}^{-1}$ ). Two sites labelled A and D were selected in the grazed salt marsh (see Fig. 1).

\subsection{Fish sampling}

In 1998, juvenile sea bass were caught in each site in July at the end of the recruitment period and in October when the fish start emigrating to deeper waters (Laffaille et al., 1998, 2000). Samplings were made during the evening ebb in order to analyse diets after residence in the salt marsh creeks. Samplings were conducted using 4 $\mathrm{mm}$ mesh fyke nets settled across the creeks accordingly to the methods of Laffaille et al. (1998). The samples were deep frozen $\left(-18^{\circ} \mathrm{C}\right)$ until examination of the gut contents. Fish were individually measured to the nearest $\mathrm{mm}$ [fork length $(F L)$ ] and weighed to the nearest $10 \mathrm{mg}$ [individual fresh body weight $(B W)$ ].

\subsection{Gut content analysis}

The entire digestive tract was removed from each seabass $>20 \mathrm{~mm}$. The number of empty stomachs was counted and a vacuity index was determined [proportion of empty stomachs $(\% \mathrm{~V})]$. Each digestive tract content was weighed to the nearest $10 \mathrm{mg}$ [digestive content fresh weight $(\mathrm{FW})]$ to determine the instantaneous food ration, \% Ir (Pawson and Pickett, 1996), as:

$\% I r=F W / B W \times 100$.

$\%$ Ir values were compared using Kruskall-Wallis and Mann-Whitney non-parametric tests (Sokal and Rohlf, 1981).

Prey were identified to species and weighed to the nearest $10 \mathrm{mg}$ [item fresh body weight $(I W)$ ]. For each sample we calculated, the occurrence $(\% F O)$, the numeric composition $(\% N)$ and the biomass composition $(\% B)$ of the food items. In order to analyse and compare the diets, we used the Main Food Index (MFI) for each food item (Zander, 1982) as modified by Laffaille et al. (1999) for each food item:

$$
M F I_{i}=\left[\left(\left[\% B_{i} \times\left(\% N_{i}+\% F O_{i}\right) / 2\right]^{1 / 2}\right) /\left(\Sigma\left(M F I_{i}\right)\right] \times 100,\right.
$$

$i=$ food item $i$.
The diets were compared using $G$ test or likelihood ratio test (Sokal and Rohlf, 1981) modified by Williams (1976).

\section{Results}

\subsection{Abiotic characteristics}

Each month, the meteorological conditions at time of sampling were similar (no wind, clear sky). The tidal amplitudes were between 11.50 and $11.85 \mathrm{~m}$ during evening ebbs (between 19.20 and $21.00 \mathrm{~h}$ GMT). Variations of abiotic conditions were, therefore, minimised between each period.

Variations were observed for temperature and salinity. In July, average water temperature was between 19.5 and $21.6^{\circ} \mathrm{C}$ for all sites, whereas in October, lower temperatures were observed in sites $\mathrm{B}$ and $\mathrm{C}\left(13.0\right.$ and $12.0^{\circ} \mathrm{C}$, respectively) compared to sites $\mathrm{A}$ and $\mathrm{D}\left(15.3\right.$ and $15.8^{\circ} \mathrm{C}$, respectively). The salinity was higher in sites closest to the minimum tide level (A) with values ranging from $35 \%$ in July $34 \%$ in October. Conversely the salinity was lower in sites closest to river outlets and farthest from the minimum tide level. In site D, salinity ranged between $20 \%$ in July and $14 \%$ in October. The central sites (B and C) had an intermediate salinity (Table 1).

\subsection{Diet in July}

459 young sea bass (average fork length $26 \pm 6 \mathrm{~mm}$ ) were caught in the four sites, and 255 stomach contents were analysed.

The instantaneous ratio ( $\%$ Ir $)$ varied between 12.0 and $17.2 \%$ (Fig. 2). $\% \operatorname{Ir}$ varied significantly between sites (Kruskall-Wallis test $=23.4, P<0.001$ ). Two groups were discriminated; \% Ir is significantly greater (U-test, all $P<0.01$ ) in bass from sites B and C (respectively, 15.4 and $17.2 \%$ ) than in sites $\mathrm{A}$ and $\mathrm{D}$ (respectively, 12.7 and $12.0 \%$ ). Within each group, no significant difference was observed between sites (U-test, all $P>0.05$ ). Thus instantaneous food ratios in sites $\mathrm{A}$ and $\mathrm{D}$ were $25 \%$ lower than those in sites B and C.

Similar observations were made for the vacuity index (Fig. 2): very few sea bass had empty stomachs as they left the salt marsh at sites $\mathrm{B}$ and $\mathrm{C}(\% V=0-3 \%)$, whereas $\% V$ was $22 \%$ at site $\mathrm{D}$ and $6 \%$ at site $\mathrm{A}$.

In July, 10 food items were identified (Table 2). Three were common and dominant: the amphipod Orchestia gammarellus, the mysid Neomysis integer, and copepods. Their average contribution was similar (mean $M F I=25-30 \%$ ), but variation were observed between sites. O. gammarellus was the main food item in sites B and $\mathrm{C}(M F I=46$ and $36 \%$, respectively) whereas it was of lesser importance in site A $(M F I=26 \%)$. In this site, copepods represent secondary prey $(M F I=27 \%)$, and 
Table 1

Abiotic characteristics (tide amplitude and time, temperature and salinity) during sampling at the four sites (A, B, C and D) during July and October

\begin{tabular}{llllll}
\hline Month & Creek & $\begin{array}{l}\text { Tide } \\
\text { amplitude } \\
(\mathrm{m})\end{array}$ & $\begin{array}{l}\text { Hour } \\
\text { of tide } \\
(\text { hGMT })\end{array}$ & $\begin{array}{l}\text { Temperature } \\
\left({ }^{\circ} \mathrm{C}\right)\end{array}$ & $\begin{array}{l}\text { Salinity } \\
(\%)\end{array}$ \\
\hline July & A & 11.50 & 19.22 & 20.8 & 35.0 \\
& B & 11.85 & 20.15 & 20.0 & 30.0 \\
& C & 11.85 & 20.10 & 21.6 & 31.9 \\
& D & 11.75 & 20.55 & 19.5 & 20.3 \\
& Actober & 11.80 & 20.40 & 15.3 & 33.7 \\
& B & 11.65 & 19.50 & 13.0 & 30.5 \\
& C & 11.80 & 20.05 & 12.0 & 29.6 \\
& D & 11.65 & 21.05 & 15.8 & 14.2 \\
\hline
\end{tabular}

$N$. integer is the main food item $(M F I=38 \%)$. In site $\mathrm{D}$, the diet was dominated by copepods $(M F I=43 \%)$. The seven other items were scarcer $(M F I<16 \%)$. The diets are significantly heterogeneous between the four sites $(\mathrm{G}$ test, all $P<0.005$ ).

\subsection{Diet in October}

118 young sea bass (average length $60 \pm 9 \mathrm{~mm}$ ) were caught in the four sites and 70 stomach contents were analysed.

Only three sea bass were caught in site $\mathrm{C}$, and were not used for the present analysis. The instantaneous
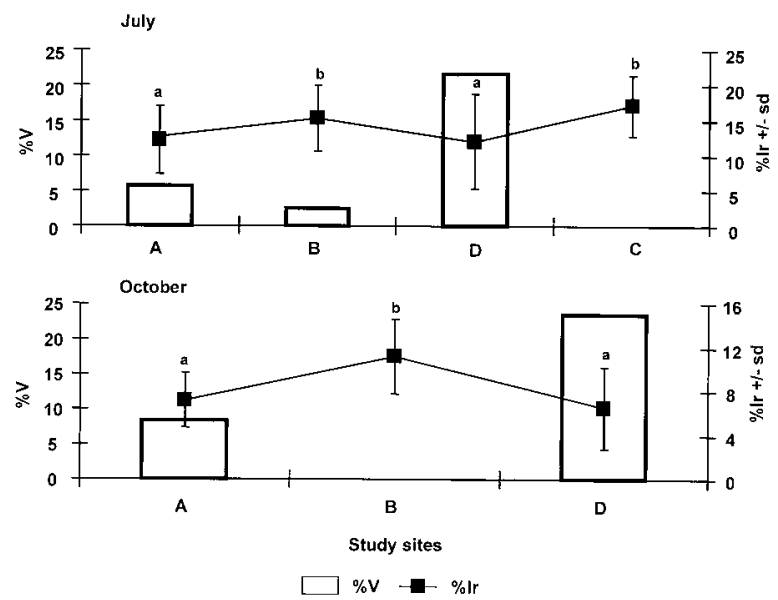

Fig. 2. Spatial fluctuations of instantaneous ratio $(\%$ Ir) and vacuity index $(\% V)$ in July and October: b, \% Ir significantly higher than a (Utest); A, B, C and D, study sites.

food ratio (\%Ir) ranged between 6.5 and $11.2 \%$ (Fig. 2). As in July, \% Ir was significantly heterogeneous between the three sites (Kruskall-Wallis test $=20.7, P<0.001$ ). $\%$ Ir was significantly higher (U-test, all $P<0.005$ ) in site B $(\% \operatorname{Ir}=11.2 \%)$ than in the two others. There was no significant difference between sites $\mathrm{A}$ and $\mathrm{D}$ (U-test $=$ 240, $P=0.368$ ).

The feeding rates were therefore $40 \%$ lower at sites A and $\mathrm{D}$ than at site B. Differences of vacuity index were similar to those observed in July (Fig. 2): none of the sea

Table 2

Food items identified in the stomach contents of young sea bass caught during ebb in sites A, B, C and D in July and October

\begin{tabular}{|c|c|c|c|c|c|c|c|c|}
\hline \multirow[t]{2}{*}{ MFI of Taxon } & \multicolumn{4}{|l|}{ July } & \multicolumn{4}{|c|}{ October } \\
\hline & $\mathrm{A}$ & $\mathrm{B}$ & $\mathrm{C}$ & $\mathrm{D}$ & A & $\mathrm{B}$ & $\mathrm{C}$ & $\mathrm{D}$ \\
\hline Insects & 0.9 & - & 1.4 & 0.5 & 7.7 & 2.1 & - & 1.1 \\
\hline Arachnids & - & - & - & - & - & 4.0 & - & 2.4 \\
\hline \multicolumn{9}{|l|}{$\begin{array}{l}\text { Crustacean } \\
\text { Decapods }\end{array}$} \\
\hline Crangon crangon & - & - & - & - & - & - & - & 4.4 \\
\hline Palaemonetes varians & - & - & - & 1.8 & 9.8 & - & - & 4.1 \\
\hline Carcinus maenas & - & 3.8 & - & - & - & - & - & - \\
\hline \multicolumn{9}{|l|}{ Amphipods } \\
\hline Orchestia gammarella & 25.7 & 45.8 & 35.7 & 11.7 & 22.4 & 71.1 & 62.5 & 23.3 \\
\hline Corophium volutator & 6.4 & 1.2 & - & 7.0 & 27.6 & 0.6 & - & 21.6 \\
\hline \multicolumn{9}{|l|}{ Isopods } \\
\hline Sphaeroma rugicauda & - & 4.6 & - & - & - & - & - & - \\
\hline Eurydice pulchra & 2.3 & - & 15.4 & 3.5 & - & 17.5 & 17.5 & 2.1 \\
\hline \multicolumn{9}{|l|}{ Mysids } \\
\hline Neomysis integer & 37.8 & 31.7 & 23.6 & 24.4 & 5.6 & 2.1 & 20.0 & 7.5 \\
\hline Copepodites & 26.8 & 12.8 & 19.2 & 42.8 & - & - & - & - \\
\hline \multicolumn{9}{|l|}{ Polychaetes } \\
\hline Hediste diversicolor & - & - & 4.9 & 8.3 & 26.5 & 2.6 & - & 33.7 \\
\hline$n$ & 84 & 38 & 16 & 87 & 11 & 21 & 3 & 26 \\
\hline
\end{tabular}

a MFI, main food index; $n$, number of stomach contents analysed. 
bass had empty stomachs as they left site B, whereas $\% V$ was $8 \%$ in site $\mathrm{A}$ and $24 \%$ in site $\mathrm{D}$.

Nine items were identified (Table 2). Compared to July, there was an absence of small items such as copepods. Moreover, the diets were significantly heterogeneous between the three sites ( $\mathrm{G}$ test, all $P<0.01)$. $O$. gammarellus was the main food item in site B $(M F I=71 \%)$. No dominant item appeared in sites A and D: the polychaete Hediste diversicolor, the amphipods $O$. gammarellus and Corophium volutator having MFI between 22 and $34 \%$. Neomysis integer was present in diets of three sites, but the food index is low $(M F I=2-$ $7 \%$ ). The five other items were also of minor importance $(M F I<18 \%)$.

\section{Discussion}

\subsection{Feeding activity}

In their first year, young sea bass, Dicentrarchus lab$\operatorname{rax} \mathrm{L}$., fed in all the sites samples, which confirms the fundamental nursery role played by macrotidal salt marshes (Laffaille et al., 1998). However, the feeding activity varied according to seasons and sites. It was lower in October and in all cases, it was lower in sites A and $\mathrm{D}$, where the P. maritima plant communities dominate, than in sites $\mathrm{B}$ and $\mathrm{C}$, which are characterised by Atriplex portulacoides plant communities. The diets were also very different among sites. In sites B and C, the diet was mainly based upon $O$. gammarellus. In the two other sites, this item was of lesser importance, and replaced by other prey such as Neomysis integer, $C$. volutator, $H$. diversicolor and copepods. In all cases, sea bass fed among the most abundant prey available at the marsh. This study confirms that small crustaceans and polychaetes constitute an important food item for juvenile sea bass (e.g. Labourg and Stéquert, 1973; Aprahamian and Barr, 1985; Pickett and Pawson, 1994; Pawson and Pickett, 1996).

\subsection{Influence of abiotic factors}

Temperature and salinity are well known to a effect feeding behaviour. Temperature has a major influence on growth and food uptake by juvenile sea bass (Alliot et al., 1983; Hidalgo and Alliot, 1988; Russell et al., 1996). Thus it would be expected that consumption of food would be lower in October than in July, irrespective of the site. Salinity is more variable among sites than among seasons. The effect of salinity on sea bass feeding behaviour is not clear. Dendrinos and Thorpe (1985) found maximum growth rates at salinities of 30\%, but Chervinski (1975) and Arias (1976) found that a lower salinity favoured growth. Stéquert (1972) argued that growth is faster in environments where variable salinity occurs, as in salt marshes. In Mont Saint-Michel bay, the lowest salinity was noted in site D where lowest $\% I r$ and highest $\% V$ are observed, but it was also the most intensively grazed area.

\subsection{Impacts of grazing}

Mont Saint-Michel Bay comprises $40 \mathrm{~km}^{2}$ of tidal salt marshes characterised by a dense halophytic vegetation. In ungrazed marshes (sites B and C), the tall A.portulacoides community provides large amounts of litter which provided both a suitable habitat and food for small resident detritivorous crustaceans such as $O$. gammarellus (Fouillet, 1986; Lefeuvre et al., 1994; Créach et al., 1997; Lefeuvre et al., 2000). However, more than $75 \%$ of the marsh is intensively grazed by more than 17 000 ewes, and the original vegetation is replaced by the less productive and shorter $P$. maritima community in the A. portulacoides community zone (Guillon, 1984; Bakker, 1989; Kiehl et al., 1996; Vivier, 1997), which provides smaller amounts of litter and less suitable habitats for Orchestia gammarellus, which is much less abundant there (Fouillet, 1986). This amphipod is a semiterrestrial species (Lincoln, 1979) with a low swimming capacity. When the creek is flooded, it is easily caught by small predators such as juvenile sea bass. Conversely, the main food items in grazed sites with $P$. maritima communities are either semi-pelagic species such as $N$. integer and $C$. volutator, or benthic invertebrates such as $H$. diversicolor and copepods which are less abundant and not as easily caught by sea bass. This probably explains why the food ratio is 25 to $40 \%$ lower in grazed areas than in ungrazed areas. Thus, the sheep grazing is responsible for a reduction of food availability and consequently of significant reduction of the growth rate that depends on feeding in salt marshes. This negative effect must certainly effect similarly other small predators such as sand gobies (Pomatoschistus minutus) for which the main food item in salt marshes is also $O$. gammarellus (Laffaille et al., 1998, 1999).

\subsection{Implications for conservation}

It is generally admitted that global change, such as the predicted sea level rise, could have major consequences on fisheries (e.g. Morris et al., 1990; Bigford, 1991). Heterogeneous habitats can modify the organisation of biological interactions within biocenoses, such as foraging, predation and competition (Coen et al., 1981; Mittelbach, 1986; Werner and Hall, 1988; Danielson, 1991). In the tidal salt marshes of Mont Saint-Michel Bay, sheep are considered as engineer species according to Lawton and Jones' (1995) definition. They are organisms which modulate directly and/or indirectly the availability of the resource for other species. Because of their grazing and trampling pressure they create and 
sustain new habitats characterised by short lawns dominated by $P$. maritima. From a conservation point of view, grazing plays a management role. Grazing at moderate stocking density creates a pattern of closely grazed and lightly grazed patches, where plant diversity is increased (Bakker et al., 1993). Intensive grazing, which is the case in the salt marshes in the Mont SaintMichel bay, may result in a low species number, due to complete or partial destruction of vegetation and topsoil by trampling (Bakker, 1989). Intensive grazing also decreased the potentiality of organic matter and nutrient export to coastal waters by modifying the soil microbiological processes which affect nitrogen and carbon cycling (Vivier, 1997). We estimate that indirectly, intensive sheep grazing reduces (1) the feeding activity of juvenile sea bass, (2) their subsequent growth rate, (3) mortality induced by trophic resource limitation as demonstrated by Crowder et al. (1987) and Miller et al. (1988). Conversely, these new habitats are favourable to other species such as wintering anseriforms (Anas penelope and Brenta bernicla). These birds consume considerable amounts of $P$. maritima in short lawns (Schricke, 1983), and this is not possible in ungrazed areas where the vegetation is too tall. In Great Britain, moderate cattle grazing permits very high densities of breeding redshank (Tringa totanus) on upper marsh (Norris et al., 1997), but it has been suggested that an increased on grazing intensity was the most likely explanation for a decline in breeding densities of the redshank (Norris et al., 1998). The findings suggest that management of salt marshes to promote one component of their biota could involve reductions in other species.

This study shows to that strong interactions exist between use and resources, with, on the one hand, exploitation of the primary production by sheep farming and on the other hand exploitation of the secondary production by juvenile sea bass. The study of interactions between organisms, whatever their origin (terrestrial, aquatic or aerial), and their common habitats whether they are exploited for reproduction, feeding or resting, is of major importance to enable sustainable management of coastal wetlands. It seems then important to be able to quantify this effect at several scales going from the individual to the landscape. Indeed, organic matter transfers through landscape compartments and particularly the role of biocenoses as biotic vectors is a basic question for landscape ecology and particularly the importance of salt marshes in preservation of the littoral secondary production and biodiversity conservation.

\section{Acknowledgements}

This study was funded by EU ELOISE RTD research projects no. ENV4 - CT97 - 0436, Programme CNRS
Environnement, Vie et Sociétés 'URBAMONT', Syndicat Mixte pour le Rétablissement du Caractère Maritime du Mont Saint-Michel and Mission du Mont Saint-Michel. We thank warmly J.M. Paillisson, A. Radureau, T. Robinet, V. Schricke and the two anonymous referees for their comments and corrections on the manuscript. The field work was supported by many colleagues, many thanks to them also.

\section{References}

Alliot, E., Pastoureaud, A., Thebault, H., 1983. Influence de la température et de la salinité sur la croissance et la composition corporelle d'alevins de Dicentrarchus labrax. Aquaculture 31, 181-194.

Aprahamian, M.W., Barr, C.D., 1985. The growth, abundance and diet of 0-group sea bass, Dicentrarchus labrax, from the Severn Estuary. Journal of the Marine Biological Association of the UK $65,169-180$.

Arias, A., 1976. Biologie du loup, Dicentrarchus labrax, de la région de Cadiz. Publication CIEM CMG 3, 1-8.

Arrhenius, F., 1996. Diet composition and food selectivity of 0-group herring (Clupea harengus L. ) and sprat (Sprattus sprattus L.) in the northern Baltic sea. ICES Journal of Marine Science 53, 701-712.

Bakker, J.P., 1989. Nature Management by Grazing and Cutting. Geobotany 14. Kluwer Academic Publisher.

Bakker, J.P., de Leeuw, J., Dijkema, K.S., Leendertse, P.C., Prins, H.H.T., Rozema, J., 1993. Salt marshes along the coast of The Netherlands. Hydrobiologia 265, 73-95.

Beeftink, W.G., 1977. The coastal salt marshes of Western Europe: an ecological and phytosociological approach. In: Chapman, V.J. (Ed.), Wet Coastal Ecosystems. Elsevier, Amsterdam, pp. 109-155.

Bigford, T.E., 1991. Sea-level rise, nearshore fisheries, and the fishing industry. Coastal Management 19, 417-437.

Boesch, D.F., Turner, R.E., 1984. Dependence of fishery species on salt marshes: the role of food and refuge. Estuaries 7, 460-468.

Bouchard, V., 1996. Production et Devenir de la Matière Organique des Halophytes dans un Marais Salé Européen en Système Macrotidal (Baie du Mont Saint-Michel). PhD dissertation, University of Rennes 1, France.

Bouchard, V., Digaire, F., Lefeuvre, J.C., Guillon, L.M., 1995. Progression des prés salés à l'ouest du Mont Saint-Michel entre 1984 et 1994. Mappemonde 4, 28-34.

Bouchard, V., Lefeuvre, J.-C., 1996. Hétérogénéité de la productivité d'Atriplex portulacoides (L. ) Aellen dans un marais salé macrotidal. Compte Rendu de l'Académie des Sciences Paris, Sciences de la Vie 319, 1027-1034.

Chervinski, J., 1975. Sea basses, (Dicentrarchus labrax (Linne) and D. punctatus (Bloch), Pisces, Serranidae) a control fish in freshwater. Aquacultere 6, 249-266.

Coen, L., Heck Jr, K.L., Abel, L.G., 1981. Experiments on competition and predation among shrimps of seagrass meadows. Ecology 62, 1484-1493.

Créach, V., Schricke, M.T., Bertru, G., Mariotti, A., 1997. Stable isotope and gut analyse to determine feeding relationships in saltmarsh macroconsumers. Estuarine, Coastal and Shelf Science 44, 599-611.

Crowder, L.B., McDonald, M.E., Rice, J.A., 1987. Understanding recruitment of Lake Michigan fishes: the importance of size-based interactions between fish and zooplankton. Canadian Journals of Fisheries and Aquatic Sciences 44, 141-147.

Danielson, B.J., 1991. Communities in a landscape: the influence of habitat heterogeneity on the interactions between species. The American Naturalist 138, 1105-1120.

Dendrinos, P., Thorpe, J.P., 1985. Effects of reduced salinity on growth and body composition in the European bass Dicentrarchus labrax (L. ). Aquaculture 49, 333-358. 
Feunteun, E., Laffaille, P., 1997. Les peuplements piscicoles de la Baie du Mont Saint-Michel. Penn Ar Bed 164, 50-56.

Fouillet, P., 1986. Evolution des Peuplements d'Arthropodes des Schorres de la Baie du Mont Saint-Michel: Influence du Pâturage Ovin et Conséquences de son Abandon. PhD dissertation, University of Rennes 1, France.

Guillon, L.M., 1984. Les schorres de la baie du Mont Saint-Michel: Unités de Végétation et Facteurs du Milieu. Report CCE, MER, Laboratoire d'Evolution des Systèmes Naturels et Modifiés, MNHN, University of Rennes 1, France.

Hidalgo, F., Alliot, E., 1988. Influence of water temperature on protein requirement and protein utilization in juvenile sea bass, Dicentrarchus labrax. Aquaculture 72, 115-129.

Kiehl, K., Eischeid, I., Gettner, S., Walter, J., 1996. Impact of different sheep grazing intensities on saltmarshes in northern Germany. Journal Vegetation Science 7, 99-106.

Kneib, R.T., 1997. The role of tidal marshes in the ecology of estuarine nekton. Oceanography and Marine Biology: an Annual Review $35,163-220$

Labourg, P.J., Stéquert, B., 1973. Régime alimentaire du bar Dicentrarchus labrax $\mathrm{L}$. des réservoirs à poissons de la région d'Arcachon. Bulletin d'Ecologie 4, 187-194.

Laffaille, P., Brosse, S., Feunteun, E., Baisez, A., Lefeuvre, J.-C., 1998. Role of fish communities in particulate organic matter fluxes between salt marshes and coastal marine waters in the Mont SaintMichel bay. Hydrobiologia 373/ 374, 121-133.

Laffaille, P., Feunteun, E., Lefeuvre, J.-C., 1999. Compétition alimentaire entre deux espèces de gobies, Pomatoschistus lozanoi (de Buen) et $P$. minutus (Pallas), dans un marais salé macrotidal. Compte Rendu de l'Academie des Sciences Paris, Sciences de la Vie 322, 897-906.

Laffaille, P., Lefeuvre, J.-C., Feunteun, E., in press. Composition of fish communities in an European macrotidal salt marshes (the Mont Saint-Michel Bay, France). Estuarine, Coastal and Shelf Science.

Lawton, J.H., Jones, C.G., 1995. Linking species and ecosystems : organisms as ecosystem engineers. In: Jones, C.G., Lawton, J.H. (Eds.), Linking Species and Ecosystems. Chapman and Hall, New York, pp. 141-150.

Lefeuvre, J.-C., 1992. Les conflits d'utilisation en zone littorale. In: Amiard, J.C., Robert, J.M. (Eds.), Le Littoral, ses Contraintes Environnementales et ses Conflits d'Utilisation. Actes du colloque 'ISOmer'. Université de Nantes, France, pp. 205-231.

Lefeuvre, J.-C., Bertru, G., Burel, F., Brient, L., Créach, V., Gueuné, Y. et al., 1994. Comparative studies of salt marsh processes: Mont Saint-Michel bay, a multi-disciplinary study. In: Mitsh, W.J. (Ed.), Global Wetlands: Old World and New. Elsevier Science BV, pp. 215-234.

Lefeuvre, J.-C., Bouchard, V., Feunteun, E., Grare, S., Laffaille, P., Radureau, A, in press. European salt marshes diversity and functioning: the case study of the Mont Saint-Michel bay, France. Wetland Ecology and Management.

Lin, J., Beal, J.L., 1995. Effects of mangrove marsh management on fish and decapod communities. Bulletin of Marine Science 57, 193, 201.

Lincoln, R.J., 1979. British Marine Amphipoda: Gammaridea. Trustees of British Museum, London.

McKee, K.L., Patrick, W.H., 1988. The relationship of smooth cordgrass (Spartina alterniflora) to tidal datums: a review. Estuaries 11, 143-151.
Miller, T.L., Crowder, L.B., Rice, J.A., Marshall, E.A., 1988. Larval size and recruitment mechanisms in fishes: toward a conceptual framework. Canadian Journals of Fisheries and Aquatic Sciences 45, $1657-1670$.

Minello, T.J., Zimmerman, R.J., 1992. Utilization of natural and transplanted Texas salt marshes by fish and decapod crustacean. Marine Ecology Progress Series 90, 273-285.

Mittelbach, G.G., 1986. Predator-mediated habitat use: some consequences for species interactions. Environmental Biology of Fishes $16,159-169$.

Morley, J.V., 1973. Tidal immersion of Spartina marsh at Bridgwater Bay, Somerset. Journal of Ecology 61, 383-386.

Morris, J.T., Kjerfve, B., Dean, J.M., 1990. Dependence of estuarine productivity on anomalies in mean sea level. Limnology and Oceanography $35,926-930$.

Norris, K.J., Cook, T., O'Dowd, B., Durbin, C., 1997. The density of redshank Tringa totanus breeding on the saltmarshes of the Wash in relation to habitat and its grazing management. Journal of Applied Ecology 34, 999-1013.

Norris, K., Brindley, E., Cook, T., Babbs, S., Brown, C.F., Yaxley, R., 1998. Is the density of redshank Tringa totanus nesting on saltmarshes in Great Britain declining due to changes in grazing management? Journal of Applied Ecology 35, 621-634.

Pawson, M.G., Pickett, G.D., 1996. The annual pattern of condition and maturity in bass, Dicentrarchus labrax, in waters around England and Wales. Journal of the Marine Biological Association of UK 76, 107-125.

Pickett, G.D., Pawson, M.G., 1994. Sea Bass-Biology, Exploitation and Conservation. Fish and Fisheries Series 12. Chapman and Hall.

Rozas, L.P., Reed, D.J., 1993. Nekton use of marsh-surface habitats in Louisiana (USA) deltaic salt marshes undergoing submergence. Marine Ecology Progress Series 96, 147-157.

Russell, N.R., Fish, J.D., Wootton, R.J., 1996. Feeding and growth of juvenile sea bass: the effect of ration and temperature on growth rate and efficiency. Journal of Fish Biology 49, 206-220.

Schricke, V., 1983. Distribution Spatio-Temporelle des Populations d'Anatidés en Transit et en Hivernage en Baie du Mont SaintMichel en Relation avec les Activités Humaines. PhD dissertation, University of Rennes 1, France.

Sokal, R.R., Rohlf, F.J., 1981. Biometry. The Principles and Practice of Statistics in Biological Research., 2nd Edition. W. H. Freeman and Company, New York.

Stéquert, B., 1972. Contribution à l'Etude de la Biologie du Bar (Dicentrarchus labrax L.) des Réservoirs à Poissons de la Région d'Arcachon. PhD dissertation, University of Bordeaux (France).

Troccaz, O., Giraud, F., Bertru, G., Lefeuvre, J.-C., 1994. Methodology for studying exchanges between saltmarshes and coastal marine waters. Wetland Ecology and Management 3, 37, 48.

Vivier, J.P., 1997. Disponibilité de l'Azote dans un Marais Salé Pâturé en Baie du Mont Saint-Michel: Conséquences sur les Echanges de Matière Organique. PhD dissertation, University of Rennes 1 (France).

Werner, E.E., Hall, D.J., 1988. Ontogenetic habitat shifts in bluegill: the foraging rate-predation risk trade-off. Ecology 69, 1352-1366.

Williams, D.A., 1976. Improved likelihood ratio tests for complete contingency tables. Biometrika 63, 33-37.

Zander, C.D., 1982. Feeding ecology of littoral gobiid and blenioids fish of the Banyuls area (Mediterranean sea). 1. Main food and trophic dimension of niche and ecotope. Vie et Milieu 32, 1-10. 